\title{
Studies on Antibacterial activity of Leaf Extracts of Rhododendron arboreum and Rhododendron campanulatum
}

\author{
Ved Prakash*, Shelly Rana and Anand Sagar \\ Department of Biosciences, Himachal Pradesh University, Shimla, (H.P.) 171005, India \\ *Corresponding author
}

\begin{abstract}
A B S T R A C T
Keywords

Rhododendron arboreum,

Rhododendron campanulatum,

Antibacterial

activity,

Agar-well

diffusion.

\section{Article Info}

Accepted:

15 March 2016

Available Online:

10 April 2016

The antibacterial activity of the methanolic and acetone leaf extracts of Rhododendron arboreum and Rhododendron campanulatum was determined in-vitro against medically important pathogens such as Escherichia coli, Yersinia pestis, Bacillus cereus, Pseudomonas aeruginosa, Listeria monocytogenes and Staphylococcus aureus following agar-well diffusion method using different concentrations $(25 \%, 50 \%, 75 \%$ and $100 \%$ ). Results showed low to significant antibacterial activity against the mentioned bacterial strains. Methanolic leaf extract was found to be more effective against selected pathogenic bacterial spp. as compared to acetone leaf extract. Further the leaf extract of both plants inhibited gram- positive bacteria more efficiently than gram- negative bacteria. Therefore, the leaf extracts of these plants can be selected for further investigation to determine their therapeutic potential.
\end{abstract}

\section{Introduction}

The use of plants for treating various diseases is as old as the human species. Plants are traditionally being used for medicinal treatment of numerous human disorders including infectious diseases caused by different microorganisms. Due to the increasing resistance of several microorganisms to commonly used antimicrobial agents, there is an urgent need for novel antimicrobial compounds. Because of available antimicrobials failure to treat infectious diseases, researchers have focused on the investigation of natural products as potential source of new bioactive compounds. According to the World Health Organization, approximately $65 \%$ of the World's populations integrate various medicinal plant products into their primary health care strategies (WHO, 2000; Farmsworth and Soejarto, 1991). Significantly, in developing countries about $80 \%$ of the population is used to prepare traditional medicine formulations from numerous plant sources (Kim, 2005). 
Plants of the genus Rhododendron belong to the woody representatives of the family Ericaceae, which are typically used in a wide range of ethno-medical applications. Rhododendron genus consists of about 1025 species, which are mainly found at higher altitudes (Chamberlaim, 1996). In India, there are about 80 species and 14 subspecies of Rhododendron, which are distributed in the Himalayan region at the altitude ranging 1500-5500 meters (Bhattacharya, 2011). Extracts of different species of Rhododendron are generally used in traditional medicine in the countries of their indigenous habitats (Rehman et al., 2010).

Rhododendron arboreum, also known as burans or gurans, is an evergreen shrub or a small tree with a showy display of bright red flowers. Phytochemically, R. arboreum was reported to contain a large number of secondary metabolites such as alkaloids, flavonoids, glycosides, saponins, tannins, steroids and phlobatanins (Nisar et al., 2011). The leaves of Rhododendron arboreum were reported for significant antioxidant property (Anpin et al., 2010) while the ethanolic extract of the flowers showed potent anti-diabetic activity (Bhandary and Kawabata, 2008). Further it was also revealed that the methanolic extract of the flowers had potent antiglycation potential in rats (Verma et al., 2011).

R.campanulatum is an evergreen gregarious shrub which is found in the outer and inner ranges of the Alpine Himalayas from Kashmir to Bhutan at altitudes of 9,000 to $14,000 \mathrm{ft}$. The leaves of this plant are said to possess several medicinal and poisonous properties (Chopra et al., 1949; Kirtikar and Basu, 1933). R. campanulatum is known for its traditional medicinal value for different ailments like body ache, sore throat, digestion, skin diseases, rheumatism, syphilis, cold and fever, etc. (Popescu and
Kopp, 2013; Pushpandan et al., 1996; Prakash et al., 2007; Kunwar et al., 2010; Paudal et al., 2011; Tantry et al., 2011). The traditional method of using this plant is to mix the leaves and stem with tobacco and snuff to get relief from hemicranias and colds (DiPasuquale, 2005; WHO, 2001; Shakya and Bista, 2002).

Therefore, in the present work an attempt has been made to analyse the antibacterial potential of methanolic and acetonic extracts of Rhododendron arboreum and $R$. campanulatum against selected pathogenic bacterial strains.

\section{Materials and Methods}

\section{Collection of Plant Materials}

Leaves of Rhododendron arboreum and Rhododendron campanulatum were collected from Churdhar area of District Sirmaur, Himachal Pradesh, India. The collected plant materials were brought to the laboratory for further analysis.

\section{Processing of Plant Material}

Leaves of $R$. arboreum and $R$. campanulatum were plucked and collected from respective plants, washed thoroughly under tap water and then with $2 \%$ Mercuric chloride. After that the leaves were cut into smaller pieces for quick drying. Cleaned leaves were shade dried for 15-20 days. The dried plant materials were crushed into fine powder with the help of pestle mortar. Finally the fine powder was stored in air tight container at room temperature.

\section{Preparation of Methanolic and Acetone Extracts}

$5 \mathrm{gm}$ dried leaves of Rhododendron arboreum and $R$. campanulatum were taken in separate Erlenmeyer flasks to which $50 \mathrm{ml}$ 
of required solvents i.e., methanol and acetone were added. The flasks were covered with aluminium foil and allowed to stand for 3-5 days for extraction. These extracts were filtered through Whatman filter paper no. 1 and evaporated at $40^{\circ} \mathrm{C}$ using rotary evaporator. The extracts were collected and weighed. Finally, stock solution of conc. $50 \mathrm{mg} / \mathrm{ml}$ was prepared.

\section{Procurement of Bacteria}

Bacterial strains used for antibacterial studies were procured from Department of Biotechnology, Himachal Pradesh University, Summer Hill Shimla, India. Pathogens used for the study were Escherichia coli, Pseudomonas aeruginosa, Yersinia pestis, Staphylococcus aureus, Bacillus cereus and Listeria monocytogenes.

\section{Revival of Pathogen}

The collected pathogens were revived in nutrient broth and stored in nutrient agar slants at $4^{\circ} \mathrm{C}$.

Screening the Antibacterial Activity of Methanolic and Acetone Extracts of Rhododendron arboreum and Rhododendron campanulatum

Screening of plant extracts (methanol \& acetone) of $R$. arboreum and $R$. campanulatum was done using agar-well diffusion method. Nutrient agar medium (Beef extract 1g, Yeast extract 2g, Sodium Chloride 1g, Peptone 5g, Agar 20g, Distilled Water $1000 \mathrm{ml}$ ) was used throughout the investigation. The medium was autoclaved at $121.6^{\circ} \mathrm{C}$ for 30 minutes and poured into petriplates. Bacteria were grown in nutrient broth for 24 hours. A $100 \mu 1$ of bacterial suspension was spread on each nutrient agar plate. Agar wells of $8 \mathrm{~mm}$ diameter were prepared with the help of sterilized stainless steel cork borer in each Petri plate. The wells in each plate were loaded with $25 \%$, $50 \%, 75 \%$ and $100 \%$ concentration of prepared leaf extracts of $R$. arboreum and $R$. campanulatum. The petri plate kept as a control contained pure solvent only. The plates were incubated at $37 \pm 2{ }^{0} \mathrm{C}$ for 24 hours in the incubation chamber. The zone of growth inhibition was calculated by measuring the diameter of the inhibition zone around the well (in $\mathrm{mm}$ ) including the well diameter. The readings were taken in perpendicular direction in all the three replicates and the average values were tabulated. Percentage inhibition of bacterial species was calculated after subtracting control from the values of inhibition diameter using control as standard (Hemashenpagam and Selvaraj, 2010).

Percentage of growth inhibition $=($ Control Test/Control) x100

Control=average diameter of bacterial colony in control.

Test=average diameter of bacterial colony in treatment sets (Kannan et al., 2009).

\section{Results and Discussion}

In the present study, two common plants namely, Rhododendron arboreum and Rhododendron campanulatum were tested for their antimicrobial properties against selected human pathogens. Results obtained revealed that the tested plant extracts possess considerable potential antibacterial activity against Escherichia coli, Yersinia pestis, Pseudomonas aeruginosa, Bacillus cereus, Listeria monocytogenes and Staphylococcus aureus (Table 1 and 2).

The screening revealed that the methanolic leaf extract of $R$. arboreum was quite effective against Listeria monocytogenes 
$(24.45 \pm 1.65 \mathrm{~mm}$ at $100 \%, 22.00 \pm 0.00 \mathrm{~mm}$ at $75 \%, \quad 18.70 \pm 2.22 \mathrm{~mm}$ at $50 \%$ and $16.00 \pm 1.05 \mathrm{~mm}$ at $25 \%$ ) and showed minimum inhibition was against Pseudomonas aeruginosa $(16.10 \pm 1.87 \mathrm{~mm}$ at $100 \%, \quad 14.15 \pm 0.24 \mathrm{~mm}$ at $75 \%$, $12.40 \pm 0.59 \mathrm{~mm}$ at $50 \%$ and $10.00 \pm 0.00 \mathrm{~mm}$ at $25 \%$ ) while the acetone leaf extract was found to be most effective against
Staphylococcus aureus $(22.50 \pm 2.54 \mathrm{~mm}$ at $100 \%, \quad 20.20 \pm 0.90 \mathrm{~mm}$ at $75 \%$, $17.65 \pm 1.94 \mathrm{~mm}$ at $50 \%$ and $15.60 \pm 1.75 \mathrm{~mm}$ at $25 \%$ ), and showed minimum inhibition against Pseudomonas aeruginosa $(15.10 \pm 0.89 \mathrm{~mm}$ at $100 \%, 13.00 \pm 1.9 \mathrm{~mm}$ at $75 \%, \quad 11.85 \pm 1.87 \mathrm{~mm}$ at $50 \%$ and $10.15 \pm 0.89 \mathrm{~mm}$ at $25 \%)$ as given in table 1 .

Table.1 Percent Inhibition of Growth of Pathogenic Bacterial spp. at Different Concentrations of Methanolic and Acetone Extracts of R. Arboreum

\begin{tabular}{|l|l|l|l|l|l|l|l|}
\hline \multirow{3}{*}{ Extract } & $\begin{array}{l}\text { Concen- } \\
\text { tration } \\
\text { in \% }\end{array}$ & \multicolumn{7}{|c|}{ Inhibition zone diameter (In mm) } \\
\hline & & E. coli & Y. pestis & P. aeruginosa & B. cereus & L. monocytogenes & S. aureus \\
\hline & Control & $0.00 \pm 0.00$ & $0.00 \pm 0.00$ & $0.00 \pm 0.00$ & $0.00 \pm 0.00$ & $0.00 \pm 0.00$ & $0.00 \pm 0.00$ \\
\cline { 2 - 8 } & 25 & $14.45 \pm 0.25$ & $15.80 \pm 1.30$ & $10.00 \pm 0.00$ & $12.45 \pm 0.77$ & $16.00 \pm 1.05$ & $14.50 \pm 0.78$ \\
\cline { 2 - 8 } $\begin{array}{l}\text { Methanolic } \\
\text { Extract }\end{array}$ & 50 & $16.20 \pm 1.27$ & $17.95 \pm 1.56$ & $12.40 \pm 0.59$ & $13.85 \pm 0.98$ & $18.70 \pm 2.22$ & $17.20 \pm 0.44$ \\
\cline { 2 - 8 } & 75 & $18.45 \pm 1.55$ & $20.50 \pm 2.00$ & $14.15 \pm 0.24$ & $15.90 \pm 1.08$ & $22.00 \pm 0.00$ & $19.60 \pm 0.67$ \\
\cline { 2 - 8 } & 100 & $20.43 \pm 0.47$ & $23.00 \pm 0.00$ & $16.10 \pm 1.87$ & $18.30 \pm 06$ & $24.45 \pm 1.65$ & $21.35 \pm 1.33$ \\
\hline \multirow{4}{*}{$\begin{array}{l}\text { Ecetone } \\
\text { Extract }\end{array}$} & Control & $0.00 \pm 0.00$ & $0.00 \pm 0.00$ & $0.00 \pm 0.00$ & $0.00 \pm 0.00$ & $0.00 \pm 0.00$ & $0.00 \pm 0.00$ \\
\cline { 2 - 8 } & 25 & $14.00 \pm 0.89$ & $13.50 \pm 1.44$ & $10.15 \pm 0.89$ & $12.15 \pm 1.55$ & $11.00 \pm 0.54$ & $15.60 \pm 1.75$ \\
\cline { 2 - 8 } & 50 & $15.90 \pm 0.70$ & $15.20 \pm 0.76$ & $11.85 \pm 1.87$ & $14.30 \pm 1.00$ & $13.45 \pm 0.66$ & $17.65 \pm 1.94$ \\
\cline { 2 - 8 } & 75 & $18.10 \pm 1.08$ & $17.60 \pm 0.70$ & $13.00 \pm 1.91$ & $17.30 \pm 0.87$ & $16.10 \pm 0.79$ & $20.20 \pm 0.90$ \\
\cline { 2 - 8 } & 100 & $19.25 \pm 0.76$ & $19.75 \pm 2.03$ & $15.10 \pm 0.98$ & $19.00 \pm 1.56$ & $19.55 \pm 0.24$ & $22.50 \pm 2.54$ \\
\hline
\end{tabular}

Each data represent mean of three replicates \pm S.D

Table.2 Percent Inhibition of Growth of Pathogenic Bacterial spp. at Different Concentrations of Methanolic and Acetone Extracts of $R$. campanulatum

\begin{tabular}{|c|c|c|c|c|c|c|c|}
\hline \multirow[t]{2}{*}{ Extract } & \multirow{2}{*}{$\begin{array}{l}\text { Concen- } \\
\text { tration } \\
\text { in } \%\end{array}$} & \multicolumn{6}{|c|}{ Inhibition zone diameter (In mm) } \\
\hline & & E. coli & $Y$. pestis & $\begin{array}{l}P . \\
\text { aeruginosa }\end{array}$ & B. cereus & $\begin{array}{l}L . \\
\text { monocytogenes }\end{array}$ & S. aureus \\
\hline \multirow{5}{*}{$\begin{array}{l}\text { Methanol } \\
\text { ic } \\
\text { Extract }\end{array}$} & Control & $0.00 \pm 0.00$ & $0.00 \pm 0.00$ & $0.00 \pm 0.00$ & $0.00 \pm 0.00$ & $0.00 \pm 0.00$ & $0.00 \pm 0.00$ \\
\hline & 25 & $16.22 \pm 0.50$ & $12.42 \pm 0.74$ & $14.10 \pm 1.01$ & $17.00 \pm 0.37$ & $18.24 \pm 2.08$ & $15.16 \pm 0.86$ \\
\hline & 50 & $18.38 \pm 0.29$ & $15.08 \pm 0.45$ & $16.60 \pm 0.33$ & $20.67 \pm 1.58$ & $21.00 \pm 0.00$ & $17.54 \pm 0.31$ \\
\hline & 75 & $21.00 \pm 0.60$ & $17.50 \pm 1.22$ & $19.76 \pm 0.58$ & $23.45 \pm 1.42$ & $24.80 \pm 0.75$ & $20.35 \pm 1.70$ \\
\hline & 100 & $23.87 \pm 1.20$ & $20.68 \pm 0.96$ & $21.90 \pm 0.44$ & $26.18 \pm 1.15$ & $28.32 \pm 0.48$ & $22.90 \pm 2.00$ \\
\hline \multirow{5}{*}{$\begin{array}{l}\text { Acetone } \\
\text { Extract }\end{array}$} & Control & $0.00 \pm 0.00$ & $0.00 \pm 0.00$ & $0.00 \pm 0.00$ & $0.00 \pm 0.00$ & $0.00 \pm 0.00$ & $0.00 \pm 0.00$ \\
\hline & 25 & $12.40 \pm 0.76$ & $16.00 \pm 0.19$ & $14.05 \pm 0.16$ & $17.90 \pm 0.00$ & $15.85 \pm 0.90$ & $14.00 \pm 1.09$ \\
\hline & 50 & $15.00 \pm 0.87$ & $18.28 \pm 0.32$ & $16.43 \pm 0.98$ & $21.00 \pm 1.32$ & $18.00 \pm 1.54$ & $17.18 \pm 0.00$ \\
\hline & 75 & $17.20 \pm 1.21$ & $21.76 \pm 0.45$ & $19.28 \pm 0.55$ & $24.92 \pm 1.47$ & $22.14 \pm 1.42$ & $21.66 \pm 0.53$ \\
\hline & 100 & $19.15 \pm 0.67$ & $23.34 \pm 0.25$ & $21.10 \pm 1.45$ & $28.22 \pm 0.77$ & $25.86 \pm 2.77$ & $25.50 \pm 1.73$ \\
\hline
\end{tabular}

Each data represent mean of three replicates \pm S.D 
Figure.1 Antibacterial Activity of $R$. arboreum against Selected Bacterial Strains: (A) Methanolic Leaf Extract; (B) Acetone Leaf Extract
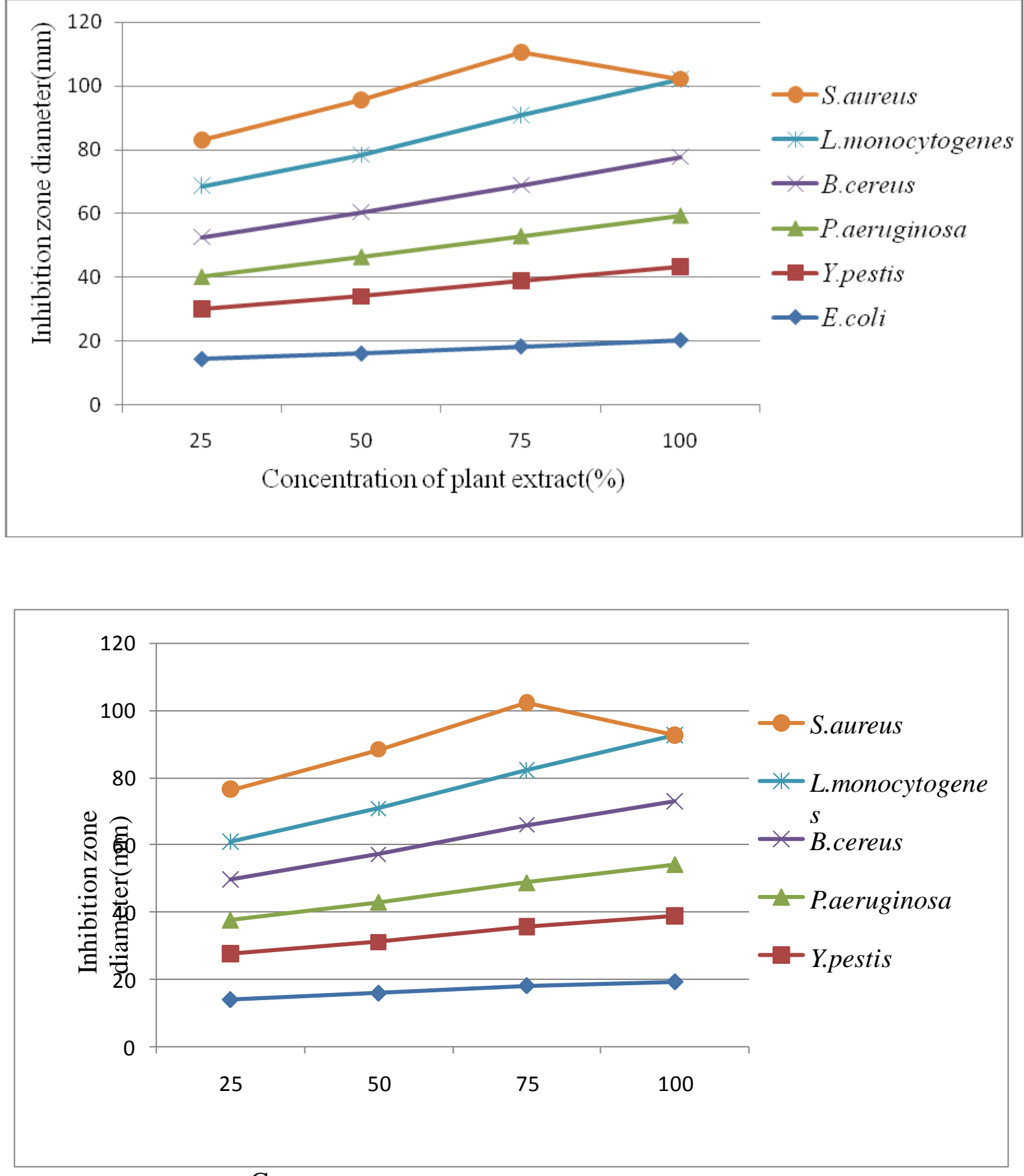
Figure.2 Antibacterial Activity of $R$. campanulatum against Selected Bacterial Strains: (a) Methanolic Leaf Extract; (b) Acetone Leaf Extract
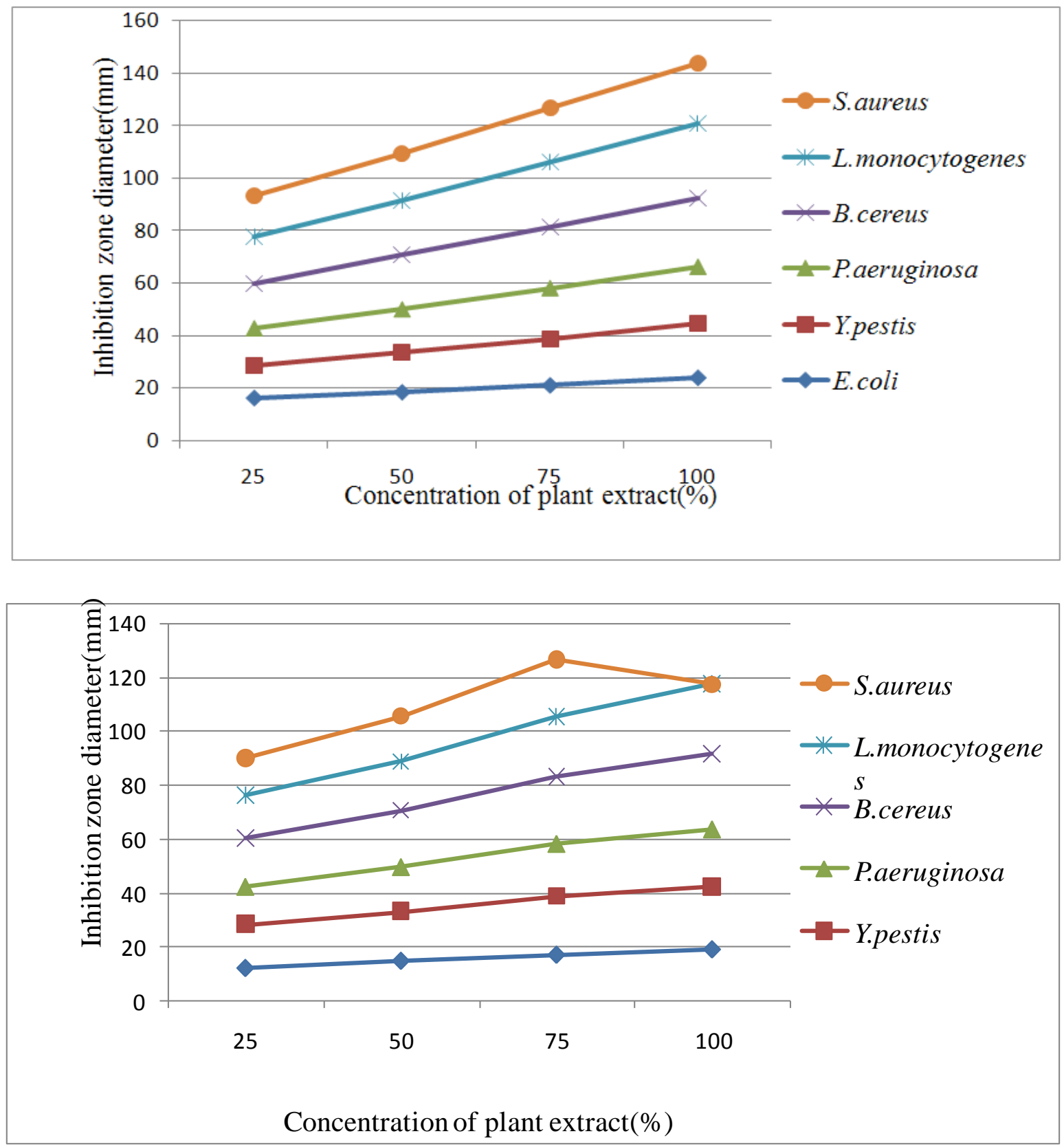

In case of $R$. campanulatum, the methanolic leaf extract was found to be most effective against Listeria monocytogenes $(28.32 \pm 0.48 \mathrm{~mm}$ at $100 \%, 24.80 \pm 0.75 \mathrm{~mm}$ at $75 \%, \quad 21.00 \pm 0.00 \mathrm{~mm}$ at $50 \%$ and $18.24 \pm 2.08 \mathrm{~mm}$ at $25 \%$ ), and it affected minimum inhibition to Yersinia pestis
$(20.68 \pm 0.96 \mathrm{~mm}$ at $100 \%, 17.50 \pm 1.22 \mathrm{~mm}$ at $75 \%, \quad 15.08 \pm 0.45 \mathrm{~mm}$ at $50 \%$ and $12.42 \pm 0.74 \mathrm{~mm}$ at $25 \%$ ). Acetone leaf extract showed considerable potential against Bacillus cereus $(28.22 \pm 0.77 \mathrm{~mm}$ at $100 \%, \quad 24.92 \pm 1.47 \mathrm{~mm}$ at $75 \%$, $21.00 \pm 1.32 \mathrm{~mm}$ at $50 \%$ and $17.90 \pm 0.00 \mathrm{~mm}$ 
at $25 \%$ ), and minimum inhibition was found in Escherichia coli $(19.15 \pm 0.67 \mathrm{~mm}$ at $100 \%, \quad 17.20 \pm 1.21 \mathrm{~mm}$ at $75 \%$, $15.00 \pm 0.87 \mathrm{~mm}$ at $50 \%$ and $12.40 \pm 0.76 \mathrm{~mm}$ at $25 \%$ ) as given in table 2 .

It was concluded from the above experimental observations that the plants Rhododendron arboreum and Rhododendron campanulatum showed potent antibacterial activity against different bacterial strains at all concentrations. Methanolic leaf extract was found to be more effective against pathogenic bacterial spp. as compared to acetone leaf extract. Further the leaf extract of both plants showed more inhibition effect in grampositive bacteria than in gram- negative bacteria. Possible reasons for this antibacterial activity of $R$. arboreum and $R$. campanulatum are presence of alkaloids, tannins, saponins, terpenes and flavonoids in their leaves (Saklani and Chandra, 2015; Paudel et al., 2011). Findings of present study are preliminary and further investigations are required to determine the exact nature of the bioactive compounds which may be present in the leaves.

\section{Acknowledgement}

Authors want to put on record their gratitude to the Chairperson, Department of Biosciences, HP University Shimla for providing Lab facilities. First author acknowledges the financial assistance provided by Indian Council of Medical Research (ICMR), New Delhi to conduct this work.

\section{Conflict of Interest}

The authors hereby declare that there is no conflict of interest regarding the manuscript and experimentation done.

\section{References}

Anpin, Raja, R.D., Prakash, J.W., Jeeva, S. 2010. Antibacterial activity of some medicinal plants used by Kani tribe, Southern Western Ghats, Tamilnadu, India. In: Trivedi, P.C. (Ed.), Ethnic Tribes and Medicinal Plants. Jaipur: Pointer Publishers. 28-45.

Bhandary, M.R., Kawabata, J. 2008. Antidiabetic activity of Laligurans (Rhododendron arboreum $\mathrm{Sm}$.) flower. J. F. Sci. Technol., 4: 61-63.

Bhattacharyya, D. 2011. Rhododendron species and their uses with special reference to the Himalayas. Assam University. J. Sci. Technol. Biol. Environ. Sci., 7: 161-7.

Chamberlain, D.F. 1996. The genus Rhododendron, its classification and synonymy. Royal Botanic Gardens, Kew.

Chopra, R.N., Badhwar, R.L., Ghosh, S. 1949. Poisonous plants of India, Manager of Publications, Delhi. 1,613.

DiPasquale, R. 2005. The aboca museum: Displaying the history of herbal medicine in Italy and Europe. J. Am. Bot. Coun., 65: 50-57.

Farnsworth, N.R., Soejarto, D.D. 1991. The conservation of medicinal plants. In: $\mathrm{O}$. A, V. H, H. S, (Eds.), Global importance of medicinal plants. Cambridge: Cambridge University Press. 25-51.

Hemashenpagam, N., Selvaraj T. 2010. Antibacterial potential of different extracts of Solanum xanthocarpum Chard and Wendt. Pl. Arch., 1: 387390.

Kannan, P., Ramadevi, S.R., Hopper, W. 2009. Antibacterial activity of Terminalia chebula fruit extract. Afr. $J$. Microbiol., 3: 180-184.

Kim, H.S. 2005. Do not put too much value on conventional medicines. $J$. 
Ethnopharmacol., 100: 37-9.

Kirtikar, K.R., Basu, B.D. 1933. Indian Medicinal Plants, Published by L.M. Basu, Allahabad, India, $2^{\text {nd }}$ Ed., Vol.2. 1461.

Kunwar, M.R., Shresta, K.P., Bussmann, R.W. 2010. Traditional herbal medicine in far-west Nepal: a pharmacological appraisal. $J$. Ethnobiol. Ethnomed., 6: 2-18.

Nisar, M., Ali, S., Qaisar, M. 2011. Preliminary Phytochemical Screening of Flowers, Leaves, Bark, Stem and Roots of Rhododendron arboreum. M.E.J. Sci. Res., 10: 472-476.

Paudel, A., Panthee, S., Shakya, S., Amatya, S., Shresta, T.M., Amatya, A.M. 2011. Phytochemical and antibacterial properties of Rhododendron campanulatum from Nepal. J. Tradit. Med., 6: 252-58.

Popescu, R., Kopp, B. 2013. The genus Rhododendron: an ethnopharmacological and toxicological review. $J$. Ethnopharmacol., 147: 42-62.

Prakash, D., Upadhyay, G., Singh, B.N., Dhakarey, R., Kumar, S., Singh, K.K. 2007. Free-radical scavenging activities of Himalayan Rhododendron. Curr. Sci. India, 92: 526-32.

Pushpangadan, P., Nyuman, U., George, V. 1996. Glimpses of Indian ethnopharmacology. Visual Security Printing Enterprise Pvt. Ltd, New Delhi. 123.

Rehman, S.U., Khan, R., Bhat, K.A., Raja, A.F., Shawl, A.S., Alam, M.S. 2010. Isolation, characterisation and antibacterial activity studies of coumarins from Rhododendron lepidotum Wall. ex G. Don, Ericaceae. Revista Brasileira de Farmacognosia, 20: 886-90.

Saklani, S., Chandra, S. 2015. Evaluation of in-vitro antimicrobial activity, nutritional profile and phytochemical screening of Rhododendron arboreum. World J. Pharm. Pharma. Sci., 962971.

Shakya, P.R., Bista, M.S. 2002. Botanical exploration and herbarium management in Nepal with special reference to reputed herbaria of the world. Proceedings of the OrientationTraining Workshop on Flora Writing; Nepal: His Majesty's Government of Nepal. 3-19.

Tantry, M.A., Khan, R., Akbar, S., Dar, A.R., Shawl, A.S., Alam, M.S. 2011. An unusual bioactive oleanane triterpenoid from Rhododendron campanulatum D. Don. Chin. Chem. Lett., 22: 575-9.

Verma, N., Amresh, G., Sahu, P.K., Mishra, N. 2011. Protective effect of ethyl acetate fraction of Rhododendron arboreum flowers against carbon tetrachloride-induced hepatotoxicity in experimental models. Indian $J$. Pharmacol., 43: 291-9.

WHO. 2000. WHO traditional medicine strategy 2002-2005. Geneva: WHO.

WHO. 2001. Legal status of Traditional Medicine and Complementary / Alternative Medicine: A Worldwide Review. Geneva: World Health Organization. 137.

\section{How to cite this article:}

Ved Prakash, Shelly Rana and Anand Sagar. 2016. Studies on Antibacterial activity of Leaf Extracts of Rhododendron arboreum and Rhododendron campanulatum. Int.J.Curr.Microbiol.App.Sci. 5(4): 315-322. doi: http://dx.doi.org/10.20546/ijcmas.2016.504.037 